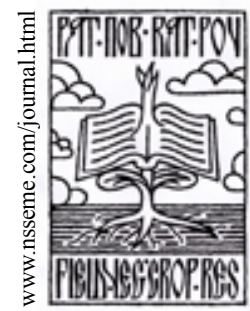

\title{
Effect of Accumulated Resistance Genes to Puccinia triticina on Transfer of Seed Proteins
}

\author{
Zoran Jerković •Željana Prijić • Veselinka Đurić
}

received: 10 September 2012, revised: 11 April 2013, accepted: 21 May 2013

published online: 28 May 2013

(C) 2013 IFVC

doi: $10.5937 /$ ratpov50-2535

\begin{abstract}
Summary: Eighteen wheat lines and varieties were classified in four groups according to different reactions to Puccinia triticina isolate of the race 77 at seedlings. Nitrogen distribution from seed, dependent of stored proteins bridge cleaving was presented across RAR (divided root with sum of up ground and root nitrogen content). Varieties expressed highest RT had RAR 0.35 or 0.37 indicating nonspecific genes like were $\operatorname{LrTc}$, Lr 34 or Lr 13 presence or accumulations. The lowest RT of 0;, never present when $\operatorname{Lr}$ near isogenic lines were tested at seedlings, characterized three lines with $\mathrm{RAR}=0.33$ fitting combinations of $\operatorname{Lr} 24(\mathrm{RAR}=0.34), \operatorname{Lr} 29(\mathrm{RAR}=0.34)$ and $\operatorname{Lr} 37 \mathrm{RAR}=0.33$. Lr 1 and 19 were excluded also by previous estimated higher influence on RAR (0.30). Lr 1 or Lr 19 were most probable ingredient in investigated genotypes for ; N RT and RAR of 0.31 as well Lr 24 was for ;N2 (0.34). RAR was decreased for only 0.01 when genes influential on RT decrease were accumulated. According to presented results the S-S linkage was not rejectable for specific resistance to parasite responsible enzymes discovering and differentiation by hydrolytic stability as well as was lower frequented in used parasite isolate.
\end{abstract}

Key words: Lr genes, proteases, wheat

\section{Introduction}

The results of resistance to plant parasites studies promoted the gene to gene relation between the host and parasites (Flour 1971). By further investigations resistance was divided on horizontal and vertical (Van der Plank 1963) as well as controlling genes as specific and nonspecific (Nelson 1978). Partial resistance was defined across high reaction type (Parlevliet 1978) without segregation of those achieved by prolonged latency period (LP). So, the mechanism of all genes was declared as same before of nowadays results. Accelerated upper parts growth (SAGR, LGR) was negatively correlated with infection efficiency as well as to wheat leaf rust resistance genes ( $\mathrm{Lr}$ ) introduced in to variety Thatcher background were divided in two divisions, trait decrease and

\footnotetext{
Z. Jerković* $\bullet$ V. Đurić

Institute of Field and Vegetable Crops, M. Gorkog 30, 21000 Novi Sad, Serbia

e-mail: zoran.jerkovic@nsseme.com

Ž. Prijić

Megatrend University, Faculty of Biofarming, MaršalaTita 39, 24300 BačkaTopola, Serbia
}

increase able. Genes from second mentioned group were not latency period (LP) prolong able and lower reaction type (RT) product able (Jerković \& Putnik-Delić 2010). The negative effects of mentioned genes on grain yield were recognized (Van der Plank 1976, The et al. 1988) and nowadays explained by disturbing of regionally optimal SAGR, character of the most importance for the regional grain yield potential (Jerković \& Prijić 2011).

Stable structure of wheat seed storage proteins was explained by enzymes transferable in the seed as were protein disulphide isomerase (PDI) (d'Aloisioet al. 2010). In drought conditions they were responsible for bounds establishment and transformation from prolamine to gluten with aim to stabilize the structure and after allow the utilization (Chiaffi et al. 1999). The local drought found as the necessary factor was obligate consequence of parasite growth also. Effects of same single resistance genes from that group introduced in near isogenic lines (NIL) on degradation of proteins from seed were defined and indicated disulphide based bonds of proteins (Wall 1971) as the enzymatic target while different RTs to same Puccinia triticina isolate of some $\mathrm{Lr}$ genes and equal influence on 
wheat protein degradation was also considered by Jerković et al. (2013). In further studies it was estimated increased degradation of the fungicides containing sulphur linkages with carbon and chlorine or metals from another side in presence of particular specific Lr genes (Jerković \& Prijić 2012a).

Hypothetical was that accumulation of specific resistance genes will be influential on gluten accelerated degradation. Such was promoted the main two practical aims of the study based on proteins from the leaf to seed transport increase as well as on efficient to RT decrease combinations discovering without interaction with parasite.

\section{Materials and Methods}

The 18 homozygous genotypes were tested according to resistance to Puccinia triticina. The spores of the race 77 (Johnston \& Browder 1966) described by intermediate RTs (reduced fructification) when applied at $\operatorname{Lr} 19$ and $\operatorname{Lr} 24$ in Thatcher based NILs were trashed on the first leaf of seedlings. The second leaf length of seedlings was compared with first one (SGR) ten days after emerging of 60 seeds sown in $2 \mathrm{dl}$ pots filled by send and grown in greenhouse on constant air temperature of $20^{\circ} \mathrm{C}$ and 11 hours of day light regime, daily watered. Genotypes with near equal values were pronounced medium $(\mathrm{M})$, those with higher second leafs for more than $1 \mathrm{~cm}$ were $\mathrm{H} 2$. The reaction types of the lines or varieties were estimated ten days after germinating and growth at same conditions (air temperature around $20^{\circ} \mathrm{C}$ ) in greenhouse according to Stakman et al. (1962) scale. Two week old not infected seedlings were grown in sand at the same conditions as were for resistance tests. Roots were cleared in water, completely dried and fine milled as well the upper parts. Their nitrogen contents were estimated in two replications by method previous used for seed protein evaluation (ICC method 105-2, 1994). Root (RC) nitrogen contents divided by AC (up ground one) + RC was declared as RAR.

\section{Results and Discussion}

For $\mathrm{H} 2$ appearance responsible genes defined as nonspecific were classified in three groups according to symptom number decreasing and SAGR increasing (Jerković \& Prijić 2013). Medium SGR of the lines proved the specific genes accumulation as lack of most influential nonspecific one $\operatorname{Lr} 22 \mathrm{~b}$. The accumulation of the resistance genes with RAR values of 0.34 as were $\operatorname{Lr} 29, \operatorname{Lr} 24$ or $\operatorname{Lr} 37$ of 0.33 when were previous tested in Nils produced RT of 0 ; followed by RAR of 0,33. Effects of single genes in NILs on parasite population in Europe also indicated mentioned genes as responsible for the trait (Bosković \& Browder 1976, Mesterhazy et al. 2000, Winzeler et al. 2000). Lr 37 and Lr 29 were not express able throw RT decrease to the used isolate at seedling stage but were LP prolong able also when exposed to population in field. The effect of $\mathrm{Lr} 1$ according to previous recognized effect on RAR or $\operatorname{Lr} 19$ on RT could be increased by any of the mentioned genes in line NS-Z 1704 very likely accompanied with Lr 22b. NS-S 111, NS-S 54 and NS-S 15 without $\operatorname{Lr} 22 \mathrm{~b}$ or lower effective nonspecific genes accumulation also declared the presence of at least two specific genes according to medium SGR. Lr 24 was likely to be present in others across intermediate decreased RT, medium SGR and RAR. According to medium SGR character above highly correlated to SAGR mentioned specific resistance genes were accompanied by genes of Lr 13 or Lr 34 type. When previous results of RAR were compared by ranking and same recent increase it could be concluded that accumulations of specific resistance genes responsible for seedling resistance were not RAR decrease able for more than 0.01 whereas significant effect of resistance genes accumulation on final RAR results was not recognized.

According to environment the interorganismal effects were defined as agricorpus (Loegering 1978) while leaf resistance genes classified in three groups according to temperature sensitivity (Browder 1985). By the recent method when seed protein degradation was focused stable lower temperatures than air one kept by daily sand watering were expected. Influence on seed proteins of $\operatorname{Lr} 1$ and $\operatorname{Lr} 19$ above recognized as temperature insensitive and Lr 24 from intermediate group was in agreement with results. According to RAR, Lr 29 had to be similar with $\operatorname{Lr} 24$ as well as $\operatorname{Lr} 37$ intermediate effective. The specificity to energetically different sulphur linkages was recognized across opposite influence of $\operatorname{Lr} 16$ and $\operatorname{Lr} 29$ on degradation of fungicides with sulphur (Jerković \& Prijić 2012a) while different hydrolytic stability by recent one. The gene products of specific $\mathrm{Lr}$ genes were at least twice heavier (Huang et al. 2003) than enzymes controlling starch or its products degradation transferable trough the wheat cell wall. Furthermore, protein transfer 
Table 1: Reaction to Puccinia triticina, LGR and nitrogen distribution from seed

Tabela 1: Reakcije prema Puccinia triticina, LGR i distribucija azota iz semena

\begin{tabular}{cccccccc}
\hline $\begin{array}{c}\text { Genotype- } \\
\text { Genotip }\end{array}$ & RT & SGR & RC & AC & RAR & $\begin{array}{c}\text { RPC }= \\
\text { RC in } \\
\text { proteins }\end{array}$ & $\begin{array}{c}\text { APC }= \\
\text { AC in } \\
\text { proteins }\end{array}$ \\
\hline NS-Z 1704 & $;$ & H2 & 2.1 & 4.6 & 0.31 & 12.0 & 26.2 \\
NS-S 111 & $; \mathrm{N}$ & M & 2.2 & 5.0 & 0.31 & 12.5 & 28.5 \\
NS-S 54 & ;N & M & 2.0 & 4.4 & 0.31 & 11.4 & 25.1 \\
NS-S 15 & $; \mathrm{N}$ & M & 1.8 & 4.0 & 0.31 & 10.3 & 22.8 \\
NS-S 175 & $0 ;$ & M & 2.2 & 4.5 & 0.33 & 12.5 & 25.7 \\
NS-Z 1498 & $0 ;$ & M & 2.4 & 4.9 & 0.33 & 13.7 & 28.0 \\
NS-N 355 & $0 ;$ & M & 2.5 & 5.0 & 0.33 & 14.3 & 28.5 \\
NS-N 36 & $;$ N2 & M & 2.3 & 4.5 & 0.34 & 13.1 & 25.7 \\
NS-N 150 & $;$ N2 & M & 2.3 & 4.4 & 0.34 & 13.1 & 25.1 \\
Simonida & 4 & M & 2.4 & 4.5 & 0.35 & 13.7 & 25.7 \\
NS 40S & 4 & M & 2.2 & 4.1 & 0.35 & 12.6 & 23.4 \\
Zvezdana & 4 & M & 2.5 & 4.7 & 0.35 & 14.3 & 26.8 \\
Partizanka & 4 & H2 & 2.4 & 4.4 & 0.35 & 13.7 & 25.1 \\
Sonata & 4 & M & 2.0 & 3.4 & 0.37 & 11.4 & 19.4 \\
Dama & 4 & M & 2.6 & 4.4 & 0.37 & 14.8 & 25.1 \\
Pobeda & 4 & H2 & 2.6 & 4.5 & 0.37 & 14.8 & 25.7 \\
Janja & 4 & M & 2.8 & 4.9 & 0.37 & 16.0 & 28.0 \\
NS-N 430 & 4 & M & 2.9 & 5.0 & 0.37 & 16.5 & 28.5 \\
\hline
\end{tabular}

from the seed started in units weighted $64 \mathrm{Kd}$ (Masson et al. 1986) similar as was of poly or disaccharides degrading enzymes. Also, when synthesis of the products and effect in germ or leaf cells was considered it was not sensed collision with PDI genes effect and purpose in maturating seed (Shewry \& Halford 2002). Synthesis of Lr genes products in leaf cells was useful across accelerated protein transport facilitated in drought conditions when growth was stopped. Consequential temporary blockade of the chlorophyll activity was also in order to solve the problem of starching. In permanent dry ones accumulation of the different nonspecific gene types related to the fast growth of the next organs on count of previous formed was more efficient or only possible solution. The $\operatorname{Lr} 34$ was previous detected as RAR low decrease able in comparison with non-specific or adult plant resistance gene Lr 22b. LR 34 fitted to be from SUT enzymatic family while influence on protein distribution was logical by Aoki et al. (2006) discover that sugar remove was the most important for seed storage activation. According to SGR results Pobeda and Partizanka carried sucrase and SUT without amylase and specific resistance genes. Simonida, NS $40 \mathrm{~S}$ and Zvezdana SGR could be caused by mixture of specific gene and sucrase. According to RAR and SGR results the Dama, Janja, NS-N-430 and Sonata were containing $\operatorname{Lr} 34$.

No entrance of nitrogen in early phases of wheat development from soil (around 40 days) was described by Vurdue \& Tonnyeck (1978) in agreement with recent results nearby to previous when plants were sown in compost. Relative amount of proteins in seed as well as their structure (Shewry \& Halford 2002) was again not influential on RAR in agreement with Jerković et al. (2013). 


\section{Conclusions}

Accumulated specific resistance genes effect on protein from seed degradation was not significant when compared to previous investigated single effects of some Lr genes in NILs. Differences of effect on parasite reduction and S-S linkages indicated energetic level and hydrolytic stability as base of specificity. Simultaneous, by different effects to the same targeted structure was explained prolonged latency period (LP) transfer to low reaction type. Applied method could serve also for detection of temporary to the parasite ineffective specific resistance genes. Fast initial differentiation from the adult plants resistance base was also facilitated while there was no possibility to discover the certain combination of genes behind RT decrease.

\section{References}

D’Aloisio, E., Paolacci, R.A., Dhanapal, A.P., Tanzarella, O.A., Porceddu, E., \& Ciaffi, M. (2010). The Protein Disulfide Isomerase gene family in bread wheat (T. aestivum L.). BMC Plant Biology, 10, 100-101.

Aoki, N., Scofield, G.N., Wang, X., Offler, C.E., Patrick, J.W., \& Furbank, R.T. (2006). Pathway of Sugar Transport in Germinating Wheat Seeds. Plant Physiology, 141(4), 1255-1263. doi:10.1104/ pp.106.082719

Bošković, M.M., \& Browder, L.E. (1976). A comparison of phatogenicity of Puccinia recondita tritici in Europe, The United States and Canada. Plant Disease Reporter, 60, 278-280.

Browder, L.E. (1985). Parasite: Host: Environment Specificity in the Cereal Rusts. Annual Review of Phytopathology, 23(1), 201-222. doi:10.1146/annurev.py.23.090185.001221

Heath, M.C. (1990). Influence of carbohydrates on the induction of haustoria of the cowpea rust fungusin vitro.Experimental Mycology, 14(1), 84-88. doi:10.1016/0147-5975(90)90090-G

Huang, L., Brooks, S.A., Li, W., Fellers, J.P., Trick, H.N., \& Gill, B.S. (2003). Map-based cloning of leaf rust resistance gene Lr21 from the large and polyploid genome of bread wheat. Genetics, 164(2), 655-64. pmid:12807786

Jerković, Z., Putnik-Delić, M. (2010). Efects of Puciniatriticina differentials and suggestion for creating a new set. Field. Veg. Crops Res. 47, 577-580.

Jerković, Z., Prijić, Ž. (2011). New reconnaissances for wheat protection from parasites, In V Symposium with international Participation Innovations in Crop and Vegetable Production, Book of abstracts, Belgrade 20-22 October, p. 73-74.

Jerković, Z., Prijić, Ž. (2012). Premises for economical wheat protection from parasites. Field. Veg. Crops Res. 49, 119-121.

Jerković, Z., Prijić, Ž. (2012a). Leaf rust specific resistance genes effect on degradation of fungicides with sulfur. Plant Protection, 2, 27-31.

Jerković, Z., Prijić, Ž., Djurić, V., Jevtić, R., Lalošević, M. (2013). Enzymes for resistance to leaf rust. Proceedings of Natural Sciences (in press).

Loegering, W.Q. (1978). Current Concepts in Interorganismal Genetics. Annual Review of Phytopathology, 16(1), 309-320. doi:10.1146/annurev. py.16.090178.001521

Masson, P., Tomè, D., \& Popineau, Y. (1986). Peptic hydrolysis of gluten, glutenin and gliadin 
from wheat grain: Kinetics and characterisation of peptides. Journal of the Science of Food and Agriculture, 37(12), 1223-1235. doi:10.1002/ jsfa. 2740371212

Mesterhazy, A., Bartos, P., Goyeau, H., Niks, R.E., \& Chosz, M. (2000). European virulence survey for leaf rust in wheat. Agronomie, 20(7), 793-804. doi:10.1051/agro:2000104

Nelson, R.R. (1978). Genetics of Horizontal Resistance to Plant Diseases. Annual Review of Phytopathology, 16(1), 359-378. doi:10.1146/annurev. py.16.090178.002043

Parlevliet, J.E. (1978). Further evidence of polygenic inheritance of the partial resistance in barley to leaf rust, Puccina hordei. Eupbytica, 27(2), 369-379. doi:10.1007/BF00043161

Shewry, R.P., \& Halford, G.N. (2002). Cereal seed storage proteins: structures, properties and role in grain utilization. Journal of Experimental Botany, 53(370), 947-958. doi:10.1093/ jexbot/53.370.947
Stakman, E.C., Stewart, D.M., \& Loegering, W.Q. (1962). Identification of physiological races of Puccinia graminis var. tritici. (pp. 1-53). Washington: United States Department of Agriculture. E-617.

The, T.T., Latter, B.H.D., Intosh, M.R.A., Elison, F.W., Brennan, P.S., Fisher, J., . . W Wilson, R.E. (1988). Grain yields of near isogenic lines with added genes for stem rust resistance. In Proc. 7 Intl. Wheat. Genetic Symp. (pp. 901-906).

Wall, J.S. (1971). Disulfide bonds: determination, location and influence on molecular properties of protein. Agr. food chem, 19(4), 6-19.

Winzeler, M., Mesterhazy, A., \& Park, R.F. (2000). Resistance of European wheat germplasm to leaf rust. Agronomie, 20(7), 783-792. doi:10.1051/ agro:2000175

van der Plank, J.E. (1963). Plant diseases: Epidemic and control. (p. 349). New York-London: Academic Press. van der Plank, J.E. (1976). Four Essays. Annual Review of Phytopathology, 14(1), 1-11. doi:10.1146/annurev. py.14.090176.000245

\title{
Efekat akumuliranih gena za otpornost prema prouzrokovaču lisne rđe pšenice na distribuciju proteina iz semena
}

\author{
Zoran Jerković • Željana Prijić • Veselinka Đurić
}

\begin{abstract}
Sažetak: Osamnaest linija i sorti pšenice su bile razdvojene u četiri grupe na osnovu različitih reakcija prema izolatu Puccinia triticina, rase 77 u stadijumu sejanaca. Umanjeni reakcioni tip (RT) definisao je prisustvo specifičnih Lr gena a poređenjem s pojedinačnim efektima u izogenim linijama dokazana njihova akumulacija u testiranim genotipova. Distribucija azota u proteinima iz semena je prikazana preko RAR vrednosti odnosno količnika sadržaja azota u korenu i sume korenskog i nadzemnog. Najviši RT je bio praćen RAR-om 0,35 i 0,37. Na osnovu ranijih rezultata indicirano je prisustvo gena u tipu Lr 34 u drugoj i akumulacija s specifičnim genom u prvoj grupi. Najniži RT 0; povezan $s$ RAR vrednošću 0,33 objašnjen je akumulacijom gena kao što su $\operatorname{Lr} 24(\mathrm{RAR}=0,34), \operatorname{Lr} 29(\mathrm{RAR}=0,34)$ i $\operatorname{Lr} 37(\mathrm{RAR}=0,33)$. Lr 1 i Lr 19 su bili isključeni na osnovu prethodno ustanovljenog jačeg uticaja na RAR $(0,30)$ kada je simultano testirani nespecifično najuticajniji Lr $22 \mathrm{~b}$ gen ispoljio vrednost 0,35 . Oni su bili mogući u akumulaciji gena odgovornih za ;N RT (RAR=0,31) a pojedinačno prisustvo Lr 24 je odgovaralo RT-u ;N2 uz RAR=0,34. Zavisnost efekta Lr 37 od spoljnih uslova je bila između Lr 1, Lr 19 i Lr 24. Na osnovu srednjeg odnosa rasta prva dva lista (LGR) specifični geni za otpornost su bili istovremeno prisutni s akumuliranim nespecifičnim genima najslabijeg efekta odnosno Lr 34 tipa ili intermedijarnim kao Lr 13. Akumulacijom srednje temperaturno osetljivih gena RAR je bio snižen za oko 0,01 . S obzirom na samo jednu ciljanu disulfidnu vezu prisutnu u delu za poprečno povezivanje protenskih lanaca razlika je bila objašnjiva preko aktivnosti genskih produkata zavisnoj od spoljnih uslova, u ovom slučaju temperature i vlage u pesku. Primenjeni metod omogućuje otkrivanje trenutno regionalno neefektnih gena za otpornost. Takođe, osnova parcijalne otpornosti postala je brzo razdvojiva na osnovu razlike u dejstvu gena.
\end{abstract}

Ključne reči: Lr geni, proteaze, pšenica 